Angela Bellia, Terracotta Female Musicians from the Sanctuary of Fontana Calda (Sicily), in (éd.) E. LAFLI, A. Muller, Figurines de terre cuite en Méditerranée grecque et romaine II. Iconographie contextes, Lille, Presses universitaires du Septentrion-Université de Lille 3, 2015, pp. 181-188.

\title{
TERRACOTTA FEMALE MUSICIANS FROM THE SANCTUARY OF FONTANA CALDA (SICILY)
}

\author{
Angela BELLIA \\ Università di Bologna
}

Résumé. Musiciennes de terre cuite du sanctuaire de Fontana Calda (Sicile). Dans les années 50 on a mis au jour dans le sanctuaire de Fontana Calda (Sicile centrale) un dépôt constitué de centaines de figurines de joueurs d'aulos, de tympanon, de cymbales, de harpe, ainsi que des groupes de joueurs d'aulos et de tympanon; elles datent d'entre la fin du VI ${ }^{\mathrm{e}} \mathrm{s}$. et le début du $\mathrm{III}^{\mathrm{e}} \mathrm{s}$. Des figurines comparables ont été retrouvées sur de nombreux autres sites de Sicile et en particulier dans des sanctuaires qui étaient comme celui de Fontana Calda consacrés à des divinités chthoniennes. Ces figurines semblent renvoyer à des cérémonies dont les protagonistes étaient exclusivement des femmes : les instruments de musique pourraient évoquer des moments précis du mythe et de la quête de Déméter à la recherche de sa fille Korè enlevée par Hadès. Les musiciennes de Fontana Calda donnent une image variée de la musique qui accompagnait tous les instants du rituel.

Mots-clefs. Instruments de musique, aulos, tympanon, cymbales, harpe, Déméter, Korè, Polystephanos

\begin{abstract}
In the Sanctuary of the Fontana Calda in Butera (central-south Sicily) was brought to light a sacred deposit. The discovery, made in the $1950 \mathrm{~s}$, revealed, among many other things, hundreds of single statuettes of aulos, tympanon, kymbala, and harp players, and groups of aulos and tympanon players. They can be dated between the end of the $6^{\text {th }} \mathrm{c}$. and the beginning of the $3^{\text {rd }} \mathrm{c}$. B.C. Many other places in Sicily have yielded these particular types, especially sanctuaries like Fontana Calda that were dedicated to "chthonic" divinities. The representations seem to refer to ceremonies where the protagonists were exclusively women, with the musical instruments perhaps evoking exact episodes of myth and the sorrowful search by the mother of Kore, who had been abducted by Hades. Music was the background in every moment of the sacred ritual of which the female musicians of Fontana Calda offer a rich and singular repertory.
\end{abstract}

Key words. Musical instruments, aulos, tympanon, kymbala, harp, Demeter, Kore, Polystephanos

Fontana Calda is a locality near Butera, a few kilometres north of Gela and is identified with the 'Sicana' Omphake (fig. 1). ${ }^{1}$ In the autumn of 1951, the archaeologist Dinu Adamesteanu discovered a votive deposit belonging to a sanctuary located outside the old town centre but still connected to it. ${ }^{2}$ The place of worship, situated under the rock of Butera that overlooks Fontana Calda, is dominated by two cliffs between which

\footnotetext{
1 D. Adamesteanu, AttiMemMagnaGr s. III (1994-1995), p. 109-117; OrLANDINI 1961, p. 145-149.

2 AdAMESTEANU 1958, p. 205-672; GUZZONE 1998, p. 243-251; GUZZONE 2003, p. 121-131.
} 
Angela Bellia, Terracotta Female Musicians from the Sanctuary of Fontana Calda (Sicily), in (éd.) E. LAFLI, A. Muller, Figurines de terre cuite en Méditerranée grecque et romaine II. Iconographie contextes, Lille, Presses universitaires du Septentrion-Université de Lille 3, 2015, pp. 181-188.

flows the torrent Comunelli, a gorge where spring waters meet. Adamestanu's excavations were on the eastern bank of the torrent, in a vineyard where, at the foot of a retaining wall built to restrict any sliding of the land, he found fragments of statuettes and terracottas. ${ }^{3}$

Traces of burning on some of the finds from the votive deposit made Adamesteanu think that there must been a rural shrine and that the site, being outside the town and near the stream, might have been dedicated to a cult associated with water as long ago as the $7^{\text {th }}$ century B.C. ${ }^{4}$ A large quantity of coroplastic material comes from the votive deposit, most of which was produced locally, from the $6^{\text {th }}$ to the $3^{\text {rd }}$ century B.C. ${ }^{5}$ This production was at its height between the second half of the $4^{\text {th }}$ and the beginning of the $3^{\text {rd }}$ century B.C. The statuettes present motifs known from Sicilian sites, specially in the area around Gela. ${ }^{6}$ This material is housed in the Regional Archaeological Museum at Gela. $^{7}$

It has been possible to identify forty three statuettes of female aulos players, ${ }^{8}$ eleven female tympanon players, ${ }^{9}$ three female figures holding kymbala on the knees, ${ }^{10}$ two female harp players, ${ }^{11}$ five groups of three female figures with double reed aulos and tympanon, ${ }^{12}$ three statuettes of girls sitting on a rock with the tympanon ${ }^{13}$, one statuette of female figure with aulos connected with the theatre. ${ }^{14}$

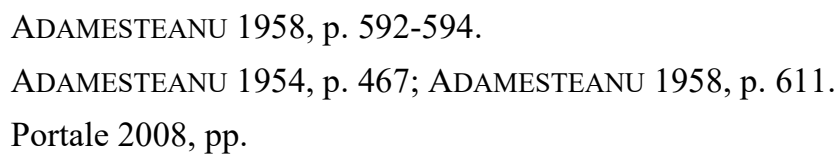

6 ADAMESTEANU 1958, p. 623-636. Among the various types, there were female figures sitting on throne, figures of pregnant women, small heads and busts of female divinities with tall polos and statuettes in the pose of offers. In the latter category, we have female figures holding a bird, probably a dove, against their breast, a baby on their left shoulder, a distaff and a basket. The number of examples reproducing a female divinity with polos decorated with little crowns and rosettes is quite significant. There were some surmounted by little leafs and female figures represented in the act of taking off their veil. Numerous are the representations of the Artemis 'Sicula' type with a bow or a torch, sometimes accompanied by a dog, a deer or a panther: they were dated the first half of the $4^{\text {th }} \mathrm{c}$. B.C. In the votive offerings at Fontana Calda, there were also statuettes of female figures holding a piglet. Furthermore, examples of statuettes with comic representations connected with the phlyax world, female statuettes of Hellenistic period, dolls, and offerings representing parts of the body were also found.

7 I would like to thank the Keeper of the Regional Archaeological Museum (RAM), Gela, Dr. Enza Cilia Platamone, and her successor, Dr. Luigi Maria Gattuso, for granting me permission to examine and to photography the terracottas kept in the Museum (here fig. 2-12) and Mr. Salvatore Burgio. I express my gratitude to the Prof. Donatella Restani, Prof. Walter Burkert and the Archaeologist Prof. Ernesto De Miro for their help.

8 ADAMESTEANU 1958, p. 636-639; BELLIA 2009, p. 114-121.

9 ADAMESTEANU 1958, p. 639-640; BeLlia 2009, p. 122-124.

10 ADAMESTEANU 1958, p. 640-641; BELLIA 2009, p. 124-125.

11 ADAMESTEANU 1958, p. 656-657; BELLIA 2009, p. 125-126.

12 ADAMESTEANU 1958, p. 639; BELLIA 2009, p. 126-127.

13 ADAMESTEANU 1958, p. 641-642; BELLIA 2009, p. 127.

14 AdAMESTEANU 1958, p. 644; BELlia 2006, p. 122. 
Angela Bellia, Terracotta Female Musicians from the Sanctuary of Fontana Calda (Sicily), in (éd.) E. LAFLI, A. Muller, Figurines de terre cuite en Méditerranée grecque et romaine II. Iconographie contextes, Lille, Presses universitaires du Septentrion-Université de Lille 3, 2015, pp. 181-188.

The statuettes of aulos players, modelled with the aulos in a vertical position, can be divided into three groups:

- in the first, from the Archaic period, the specimens have almond-shaped eyes and cheeks swollen in the act of playing. The instrument has divergent pipes of different lengths. The player is represented with her fingers placed on the pipes, with her index fingers slightly parted from the other fingers, the left hand one more than the right hand. The upper part of the instrument is covered by the player's lips (fig. 2). ${ }^{15}$

- aulos players of the Classical period belong to the second group. ${ }^{16}$ In the figures, the pipes of the instruments are depicted in different ways. They can be of the same length but slightly divergent, divergent with a longer left hand pipe, or divergent with a longer right hand pipe. The female aulos players wear a chiton and their heads are covered by a himation (fig. 3). ${ }^{17}$

- the aulos players of the Hellenistic period belong to the third group. ${ }^{18}$ The instrument has divergent pipes of the same length, divergent with a longer left hand pipe, divergent with a longer right hand pipe. The statuettes have their hair gathered in a chignon on top of their head (fig. 4). ${ }^{19}$ Both the examples of the second group and those of third group are made from the sandy clay of Butera and therefore are made locally by means of moulds. ${ }^{20}$

One particular representation is that which recurs in a small head of the Hellenistic period, probably representing the 'Polystephanos' playing the double reed aulos (fig. 5). ${ }^{2}$

The statuettes of tympanon players are dated to the Hellenistic period. ${ }^{22}$ They are represented with the tympanon held near their chest with the right hand stretched out towards the instrument as if about to play (fig. 6). ${ }^{23}$ One particular gesture is represented in the figures that hold the tympanon on their left hip while with their right hand they hold the hem of their chiton (fig. 7). ${ }^{24}$ The statuettes of the tympanon players, made of local clay, were produced by means of moulds. ${ }^{25}$

The statuettes of the Hellenistic period belong to the typology of kymbala player that represents a nude, female figure with slightly marked hips and breasts and a flat stomach, who is holding a truncated conical shaped kymbalon against her legs (fig. 8). ${ }^{26}$

The typology of harp players of the Hellenistic period are represented by two statuettes whose state of preservation only permits us to propose that the harp is angular. Both

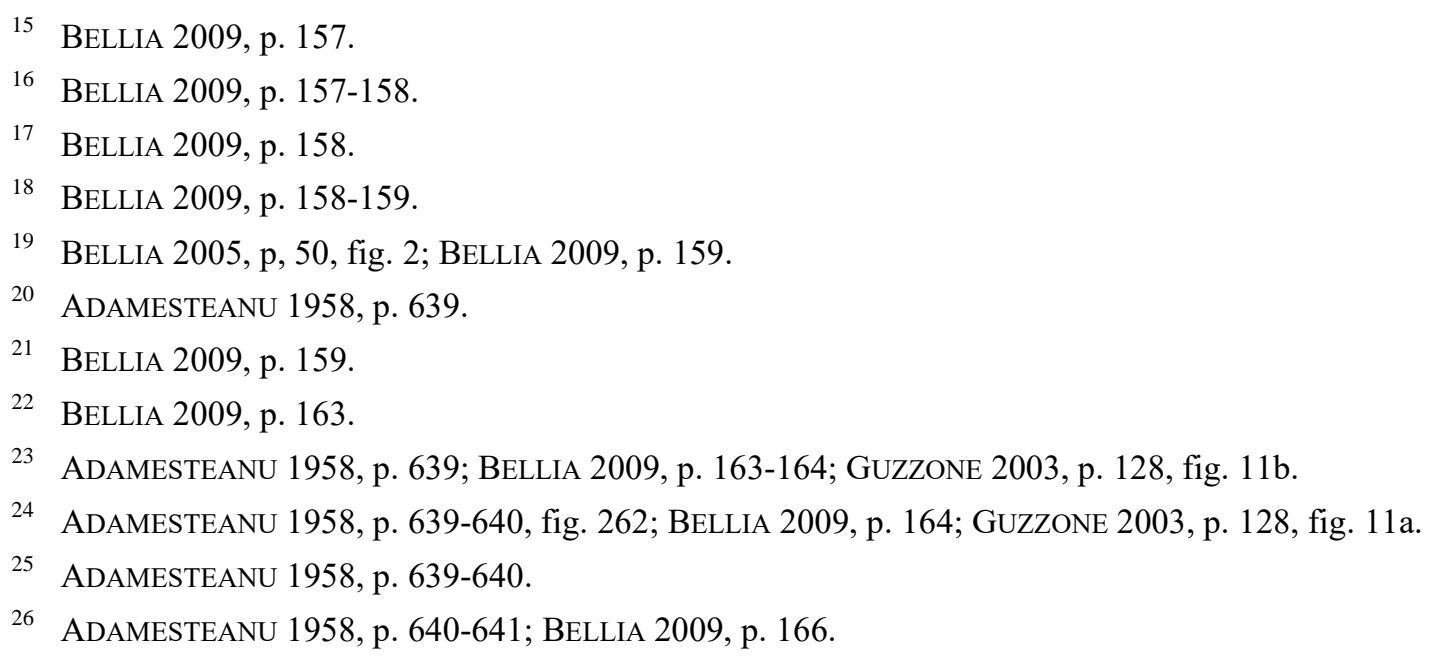


Angela Bellia, Terracotta Female Musicians from the Sanctuary of Fontana Calda (Sicily), in (éd.) E. LAFLI, A. Muller, Figurines de terre cuite en Méditerranée grecque et romaine II. Iconographie contextes, Lille, Presses universitaires du Septentrion-Université de Lille 3, 2015, pp. 181-188.

figures are wearing poloi decorated with little crowns and globe-shaped earings. They show no traces of the sand typical of the clay of Butera, so they are considered as imported products (fig. 9). ${ }^{27}$

A category of images with musical representations that is quite widespread in Sicily ${ }^{28}$ is the group of three female figures of the Hellenistic period also found in the votive deposit at Fontana Calda. However, only one example was retrieved intact. The group, made in the sandy clay of Butera, comprises three females standing on a rectangular plinth. The figure on the left is playing a convergent, equal-length double reed aulos held with both hands against the breast. She is wearing spherical earings and a himation that falls from her right arm and goes around and over her left arm; her hair is gathered in a chignon. The central figure is holding a tympanon on the left hip with her right hand seeming to reach out to the instrument. She is wearing a truncated, cone-shaped polos, chiton, and himation that falls from her right arm and goes round and over her left arm. The figure on the right is wearing a pleated chiton, the hem of which seems to be held in her left hand, and himation that falls from her right arm over her left arm that forms pleats round the body. The hair is gathered in a chignon (fig. 10). ${ }^{29}$

Another type of musician of the Hellenistic period found among the Fontana Calda offerings is the female figure sitting on a rock and holding a tympanon on her knee. Her head and chest conform to a frontal plane, while her legs are in profile. In her right hand she has a thyrsus, while her left hand is resting on a small pillar. She is wearing a belted chiton and himation over her left arm so that it covers her legs. At her feet there is a dog looking upwards. This type of female figure made of local clay (fig. 11). ${ }^{30}$

Among the finds from the sanctuary there is a female aulos player belonging to the world of the theatre. The figure holds the instruments against her breast. The instrument has slightly divergent pipes that extend down her body to a swollen stomach. Her cheeks are puffed out because she is playing the instrument; her eyes and nose are bulbous; her hair is parted down the middle of her head, is thick at the temples, and is tied up in a ribbon. The figure wears himation and her slim legs seem about to dance. She made in the clay of Butera (fig. 12). ${ }^{31}$

Many other sites in Greek Sicily dating from the $6^{\text {th }}$ to the $3^{\text {rd }}$ century B.C. have yielded these particular types of terracottas, especially those sanctuaries that were dedicated to Demeter, the goddess of human and chtonic fertility. It has been determined that the these figurines with musical representation can be placed in relationship with practices relative to her spheres of ritual and cult. ${ }^{32}$

27 AdAMESTEANU 1958, p. 656-657; BELLia 2009, p. 167.

28 BELLIA 2009, p. 168-169.

29 AdAMESTEANU 1958, p. 639, fig. 260; D. AdAMESTEANU, Nsc 12 (1958), p. 335-387; Bellia 2009, p. 169; GUZZONE 2003, p. 127, fig. 10; PANVINI 1998, p. 247.

30 AdAMESTEANU 1958, p. 641, fig. 265; Bellia 2009, p. 164; GuZzone 1998, p. 246, fig. B; ORLANDINI 1968, p. 56, fig. 40B.

31 Adamesteanu 1958, p. 644, fig. 271; Bellia 2009, p. 174; BernabÒ BrEA 2002, p. 77, fig. 67.

32 BELLia 2009, p. 157-175. 
Angela Bellia, Terracotta Female Musicians from the Sanctuary of Fontana Calda (Sicily), in (éd.) E. LAFLI, A. Muller, Figurines de terre cuite en Méditerranée grecque et romaine II. Iconographie contextes, Lille, Presses universitaires du Septentrion-Université de Lille 3, 2015, pp. 181-188.

If the presence of music emerges amply from the documentation of the excavations, it recurs much less frequently in the written sources regarding Sicily ${ }^{33}$. The limited information provided by literary sources underscores the need to deepen our knowledge of the role of music in archaeological contexts to which the presence of statuettes with musical representations is associated. The Sicilian documentation must undergo a more extensive analysis that considers other Greek sites in Magna Grecia and elsewhere around the Mediterranean.

33 BELLIA 2009, p. 179-184. 
Angela Bellia, Terracotta Female Musicians from the Sanctuary of Fontana Calda (Sicily), in (éd.) E. LAFLI, A. Muller, Figurines de terre cuite en Méditerranée grecque et romaine II. Iconographie contextes, Lille, Presses universitaires du Septentrion-Université de Lille 3, 2015, pp. 181-188.

\section{BIBLIOGRAPHY}

Référence à intégrer dans Bibliographie cumulative

Référence déjà présente dans Bibliographie cumulative

Référence donnée sous forme abrégée dans les notes de bas de page

ADAMESTEANU 1954

ADAMESTEANU 1958

ADAMESTEANU 1958

ADAMESTEANU 1995

BELLIA 2005

BELLIA 2009

BERNABÒ BREA 2002

GUZZONE 1998

GUZZONE 2003

ORLANDINI 1961

ORLANDINI 1968

PANVINI 1998

PORTALE 2008
D. ADAMESTEANU, «ПO $\Lambda$ Y $\Sigma T E \Phi A N O \Sigma$ $\Theta E A ~ »$, RendLinc 9 (1954), p. 467-469

D. AdAmesteanu, «Butera: Piano della Fiera, Consi e Fontana Calda. Fontana Calda. Scoperta della stipe votiva di un santuario campestre», MonAnt 44 (1958), p. 205-672

D. AdAMESTEANU, «Scavi e scoperte dal 1951 al 1957 nella provincia di Caltanissetta », Nsc 12 (1958), p. 335-387

D. AdAMESTEANU, « Butera. Sede temporanea di una colonia greca arcaica? », AttiMemMagnaGr s. III (1994-1995), p. 109-117

A. BELLIA, «Coroplastica con raffigurazioni musicali della Sicilia Greca », Aulos. Studi e ricerche di Archeologia musicale della Sicilia e del Mediterraneo 1 (2005), p. 49-63

A. BELliA, «Coroplastica con raffigurazioni musicali nella Sicilia greca (VI-III sec. a.C.) », Biblioteca di Sicilia Antiqua 3 (2009)

L. BERNABÒ BREA, Terrecotte teatrali e buffonesche della Sicilia orientale e centrale (2002)

C. GuZzone, « Butera: santuari e fattorie di età greca nel territorio », in PANVINI 1998, p. 243-251

C. Guzzone, « La stipe o deposito votivo di Fontana Calda », in R. PANVINI (éd.), Butera dalla preistoria all'età medievale (2003), p. 121-131

P. ORLANDINI, «Omphake e Maktorion », Kokalos 7 (1961), p. 145149

P. ORLANDINI, «Gela. Topografia dei santuari e documentazione archeologica dei culti », RIA 15 (1968), p. 20-66

R. PANVINI (éd.), Gela. Il Museo archeologico. Catalogo (1998)

E.C. Portale, « Coroplastica votiva nella Sicilia di V-III secolo a.C.: la stipe votiva di Fontana Calda a Butera », Sicilia Antiqua 5 (2008), p. 9-57. 
Angela Bellia, Terracotta Female Musicians from the Sanctuary of Fontana Calda (Sicily), in (éd.) E. LAFLI, A. Muller, Figurines de terre cuite en Méditerranée grecque et romaine II. Iconographie contextes, Lille, Presses universitaires du Septentrion-Université de Lille 3, 2015, pp. 181-188.

\section{ILLUSTRATIONS}

Fig. 1: The Central South of Sicily.

Fig. 2: $\quad$ Female aulos player, hair gathered in a big fringe on forehead. H: $8 \mathrm{~cm} .6^{\text {th }}$ c. B.C. Gela, RAM, N. 6333.

Fig. 3: Female aulos player, head covered by himation. End $6^{\text {th }}-$ beginning $5^{\text {th }}$ c. B.C. Gela, RAM, N. 5745.

Fig. 4: Female aulos player, hair gathered on the top of head; ear-rings. End $4^{\text {th }}$ - beginning $3^{\text {rd }}$ c. B.C. Gela, RAM, N. 6341.

Fig. 5: Small head of the 'Polystephanos' playing the double reed aulos. $4^{\text {th }}$ c. B.C. Gela, RAM, N. 6368.

Fig. 6: Female tympanon player, hair gathered in a chignon without himation. End $4^{\text {th }}$ c. - beginning $3^{\text {rd }}$ c. B.C. Gela, RAM, N. 5752.

Fig. 7: Female tympanon player; hair gathered under polos and chiton, the hem of which is held in the right hand. H: $12-14$ cm. $3^{\text {rd }}$ c. B.C. Gela, RAM, N. 6330.

Fig. 8: Female figure holding truncated cone shaped kymbala. $\mathrm{H}: 17 \mathrm{~cm}$. End $4^{\text {th }} \mathrm{c}$ - - beginning $3^{\text {rd }}$ c. B.C. Gela, RAM, N. 5782.

Fig. 9: $\quad$ Female figure holding a harp (?). $3^{\text {rd }}$ c. B.C. Gela, RAM, N. 5747.

Fig. 10: Group of players: figure on the left playing aulos, central figure playing tympanon, figure on the right standing; side figures wearing pointed hats, central figure wearing polos. H: $13,5 \mathrm{~cm} .4^{\text {th }}$ c. B.C. Gela, RAM, N. 6376.

Fig. 11: Female figure sitting on a rock, holding tympanon. H: $15 \mathrm{~cm} .4^{\text {th }}$ c. B.C. Gela, RAM, N. 6374 .

Fig. 12: Grotesque female figure playing aulos. $4^{\text {th }}$ c. B.C. Gela, RAM, N. 6345. 
Angela Bellia, Terracotta Female Musicians from the Sanctuary of Fontana Calda (Sicily), in (éd.) E. LAFLI, A. Muller, Figurines de terre cuite en Méditerranée grecque et romaine II. Iconographie contextes, Lille, Presses universitaires du Septentrion-Université de Lille 3, 2015, pp. 181-188.

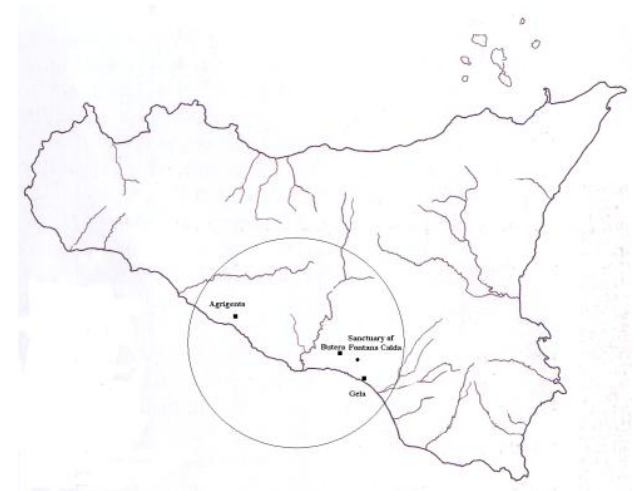

Fig. 1

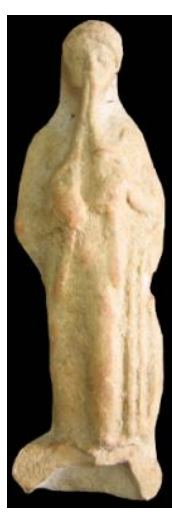

Fig. 2

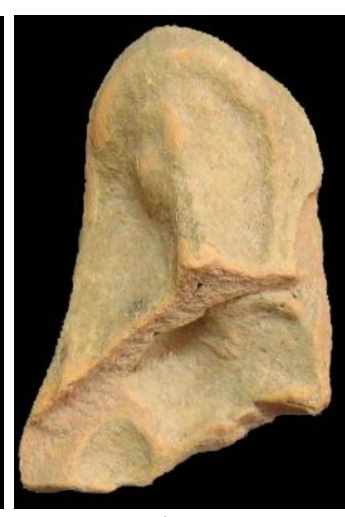

Fig. 3

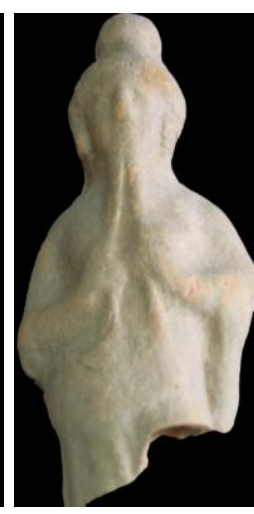

Fig. 4

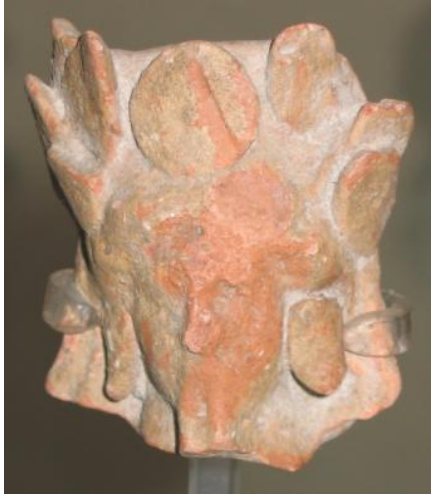

Fig. 5

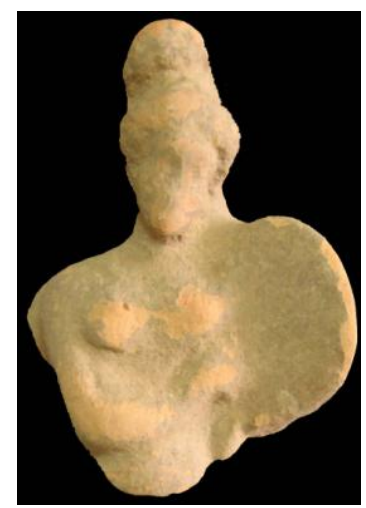

Fig. 6

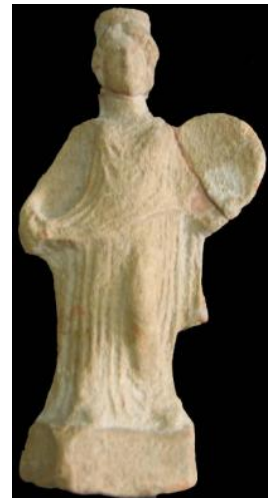

Fig. 7

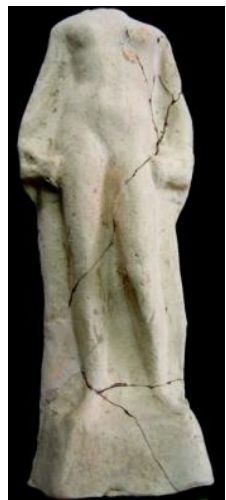

Fig. 8 
Angela Bellia, Terracotta Female Musicians from the Sanctuary of Fontana Calda (Sicily), in (éd.) E. LAFLI, A. Muller, Figurines de terre cuite en Méditerranée grecque et romaine II. Iconographie contextes, Lille, Presses universitaires du Septentrion-Université de Lille 3, 2015, pp. 181-188.

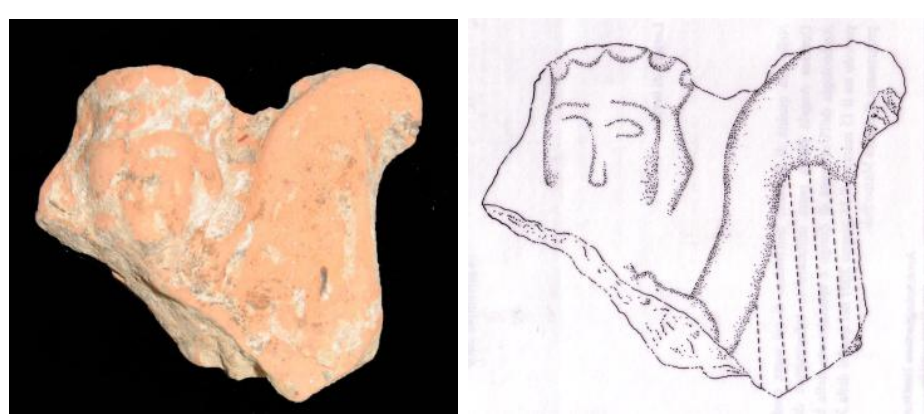

Fig. 9

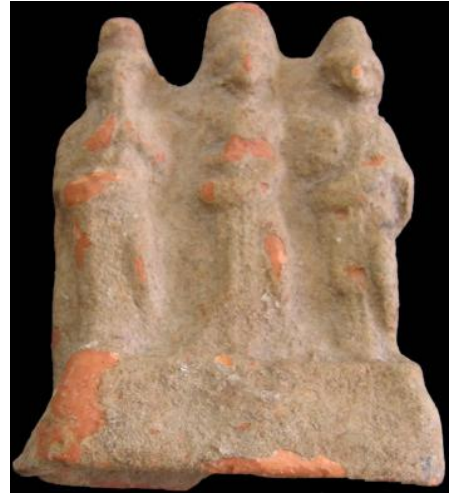

Fig. 10

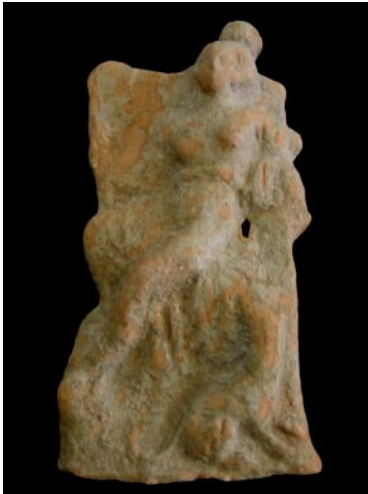

Fig. 11

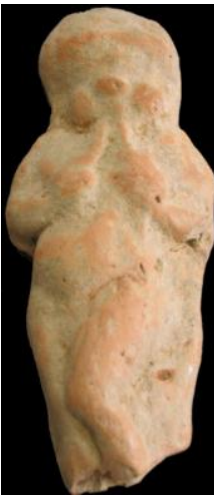

Fig. 12 